\title{
XV. VE XIX. YÜZYILLAR ARASINDA OSMANLI PARA VAKIFLARI VE MODERN FINANS KURUMLARININ KARȘILAȘTIRILMASI
}

\author{
C EM KORKUT* \\ Ankara Yıldırım Beyazıt Üniversitesi \\ MEHMET BULUT ${ }^{* *}$ \\ Istanbul Sabahattin Zaim Üniversitesi
}

Öz

Günümüzde modern devletler tarafından vatandaşlara sağlanan çoğu hizmetler, Osmanlı döneminde vakıflar tarafından sağlanıyordu. İslâm dininin toplumsal hayat üzerindeki etkisinin yüksek olması insanları vakıf kurmaya iten önemli etkenlerin başında geliyordu. Hayırseverler tarafından kurulan vakıflar, dini hizmetler, eğitim, altyapı vb. toplumsal intiyaçları finanse etmekteydi. Para vakıfları, toplumun intiyaçlarını finanse eden vakıf türlerinden birisidir. Sermayesi nakit paradan oluşan bu vakıflar intiyacı olan girişimcilere İslâmî usullere göre finansman sağlamıştı. Para vakıfları Osmanlıların son dönemlerine kadar işleyişini devam ettiren kurumlar olmuştur. Osmanlıların, aynı dönemde Avrupa'daki modern finansal kurumların gelişmesine karşı para vakıfları ile bu kurumların işlevlerini yerine getirmesi, Osmanlı iktisadi ve finansal zihniyetini anlamak açısından önemlidir. Bu çalışmanın amacı birincil kaynaklarından incelenen para vakıfları ile Osmanlı iktisadi zihniyetini analiz etmektir. Ayrıca aynı dönemde faaliyet gösteren ve para vakıfları ile çağdaş olarak Avrupa'da faaliyet gösteren finansal kurumlar da incelenecek ve iktisadi zihniyetler arasında karşılaştırma yapıımaya çalışılacaktır.

Anahtar Kelimeler: Para vakıfları, Osmanlı iktisadi zihniyeti, Rumeli, modern finans kurumları, İslam iktisadı ve finansı

\section{A COMPARISON BETWEEN OTTOMAN CASH WAQFS AND MODERN FINANCIAL INSTITUTIONS BETWEEN $15^{\text {th }}$ AND $19^{\text {th }}$ CENTURIES}

\begin{abstract}
Most of the services provided by modern states to their citizens today were provided by the waqfs during the Ottoman period. The fact that the influence of Islamic religion on the social life was high was one of the most important factors driving people to establish the waqfs. The waqfs founded by philanthropists financed such social needs as religious services, education and infrastructure. The cash waqfs (CWs) were one of the waqf types that financed the needs of the society. The CWs whose capital was cash money provided financial sources to entrepreneurs who were in need of cash according to Islamic methods. The CWs continued to function until the last period of the Ottomans. That the Ottomans used CWs to carry out the functions of the modern financial institutions of Europe is important to understand the Ottoman economic and financial mentality. By using the primary sources, this study aims to analyze the Ottoman economic mentality through studying CWs. In addition, the financial institutions operating in Europe in the same period will be examined and a comparison will be made between the two economic mentalities.
\end{abstract}

Keywords: Cash waqfs, economic mentality of Ottomans, Rumelia, modern financial institutions, Islamic economics and finance

* Araştırma Görevlisi, Ankara Yıldırım Beyazıt Üniversitesi, İktisat bölümü, E-mail: ckorkut@ybu.edu.tr

** Prof. Dr., İstanbul Sabahattin Zaim Üniversitesi, İktisat Bölümü, E-mail: mehmet.bulut@izu.edu.tr 
Medrese, mektep gibi eğitim hizmetlerinden cami, mektep, tekke gibi dini hizmetlere, kaldırım, köprü, saat kulesi gibi altyapı hizmetlerinden aşevleri, fakirlere yemek dağıtımı gibi hayır hizmetlerine kadar birçok hizmet Osmanlılar'da vakıflar tarafindan finanse edilmekteydi. Vakıf sistemi Osmanlı'da en ücra köylere kadar ulaşabilmişti. Toplumun ihtiyaçlarını karşılamadaki başarısı, dini arka planı ve bölgesel kurumlar olmaları sebebiyle yaygınlaşan vakıflar, Osmanlılar'da kurumsallaşmanın ve ekonomik, sosyal ve kültürel hayattaki etkisinin zirvesine ulaşmıştır. Bu başarı sayesinde Osmanlı İmparatorluğu bir vakıf medeniyeti olmuştur. İnsanlarının ince düşünceleri ve dönemin sorunları birçok amaçla vakıf kurulmasına sebep olmuştur. Bu vakıflar sayesinde, Osmanlıların mirası günümüze aktarılabilmiştir. Günümüzde ayakta olan birçok cami, imarethane, köprü, medrese, mescit, tekke gibi eserler bunu vakıfların bu hizmetleri finansmanına borçludur. Orhan Gazi'nin (Ö: 1326) 14. yüzyılın ilk çeyreğinde İznik'te müderrisliğini Davûd-1 Kayserî̀nin yaptığı medrese için kurmuş olduğu vakıf Osmanlıların ilk vakfıdır. Kurduğu bu vakfın ihtiyaçlarına yetecek kadar gayrimenkul vakfeden Orhan Gazi, Adapazarı, Bursa ve Kandıra'da camiler, imarethaneler, medreseler, misafirhaneler ve zaviyelerin ihtiyaçları için de vakıflar kurmuş ve buralarda görevlilerin istihdamını sağlamıştır (Berki, 1962, ss. 127-129).

Vakıflar, Osmanlılar'da sadece zengin, toplumda ileri gelen yahut yönetici sınıftan olan hayırseverlerin kurduğu kurumlar olmamış, reaya diye tabir edilen sıradan vatandaşlar da tek başlarına yahut bir araya gelerek vakıflar kurmuştur. Günümüz modern devletlerinin vatandaşlarına sunduğu hizmetlerin önemli bir kısmı vakıflar tarafından tesis edilmekteydi. Camiler, hastanenler, imarethaneler, kaldırımlar, köprüler, kütüphaneler, medreseler, mektepler, mescitler, suyolları, tekkeler, zaviyeler vb. diğer kurumlar vakıflar tarafindan finanse edilmekte, bu kurumlarda çalışanların ücretleri vakıflar tarafından karşılanmaktaydı. Devletin hizmet yükü vakıflar sayesinde hafiflemekteydi. Ayrıca fakirlere yardım gayesiyle kurulan vakıflar da mevcuttu. Bu vakıflar gerek yemek yardımı gerek çeyiz yardımı gibi hizmetler sunarak hayır hizmetleri gerçekleştirmekteydi. Bunların yanında Hac vazifesini ifa etmek isteyenlerin Hacca gönderilmesini sağlayan, Harameyn olarak bilinen iki mübarek beldeye (Mekke, Medine) orada görülecek hizmetler için nakit gönderen vakıflar vardı. Bu vakıflar arasında para vakıfları olarak bilinen vakıf türü bu çalışmanın üzerinde durduğu teorinin temelini oluşturacaktır. 
Avrupa'da anonim şirket, banka, borsa gibi girişimcilerin ve kurumların finansman ihtiyacını sağlayan kuruluşların oluştuğu dönemde Osmanlıların kendilerine özgü bir kurum olarak benimseyip yaygınlaştırdıkları para vakıfları, finansal açıdan Osmanlıların uzun dönem yüksek kâr etme güdüsü, maddi varlıklara sahip olma iştahı ve sömürgecilik faaliyetleri ile de desteklenen bu kurumlara karşı direnebilmesini sağlamıştır. İlk bankanın kurulduğu 19. yüzyılın ikinci yarısına kadar para vakıfları sayesinde insanların nakit ihtiyaçları sağlanmış ve bu vakıfların birincil hedefi olan hayır hizmetleri devam etmiştir. Merkantilizm ve devamı niteliğindeki devlet destekli kapitalizm ile Avrupa'da tamamen maddi zenginlik temelli, servetlerin belirli kişilerde toplanmasını sağlayan ve zenginliği tabana yaymayan bir sistem kurulurken, Osmanlılar aynı dönemde Avrupa'nın çok yakın komşusu olmalarına rağmen finansal ve iktisadi zihniyetleri ile bu değişime direnmiş ve başarılı olmuştur.

Bu çalışmada, birincil kaynaklardan faydalanılacak ve Türkiye Cumhuriyeti Başbakanlık Vakıflar Genel Müdürlüğü Arşivi’nde bulunan vakıf dokümanlarından (vakfiyelerden) yola çıkılarak Osmanlı finansal zihniyeti tahlil edilmeye çalışılacaktır. Osmanlı Rumeli coğrafyasının çeşitli bölgelerinden ve farklı tarihlerden vakfiyeler incelenecektir ve örnek para vakıfları, vakfiyeleri üzerinden analiz edilecektir. Ayrıca aynı dönemde Avrupa'da ortaya çıkmış ve günümüzdeki modern finansal sistemin kurumlarının temelini oluşturan kurumlar da incelenecek ve finansal anlamda yapisal ve zihinsel açıdan karşılaştırma yapılacaktır.

\section{Para Vakıfları}

İslâm medeniyetinde vakıf terimi toplumun ihtiyaçlarını görmek için sahibi tarafından bağışlanan ve tahsis edilen malları tanımlamak için kullanılmıştır. Vakfedilen mal, vakfedildikten sonra sahibinin mülkiyetinden çıkmakta ve Allah'ın rızasını kazanmak için kurulan vakfın mülkiyetine geçmektedir. Çeşitli türleri olan vakıfların Osmanlılar tarafından yaygınlaştırılan ve kurumsallaştırılan türlerinden birisi para vakıflarıdır.

Sermayesinin tamamını veyahut bir kısmını vakfedilmiş nakit paranın oluşturduğu vakıflara para vakfı denilmektedir. Gayrimenkul vakıflarında, gayrimenkullerin kira gelirleri vakfin amaçları doğrultusunda değerlendirilirken, para vakıflarında kurucu tarafindan vakfedilen para bu amaçla değerlendirilmiştir. İslâmî usullerle işletilen nakit paradan gelen gelir vakfin 
amaçları doğrultusunda harcanmıştır. Gayrimenkullerin harap olma ve yanma gibi riskleri karşısında paranın misline ulaşılmasının kolay olması ve işlem maliyetlerinin düşük olmasından ötürü vakfedilmesi önemli tartışmaları da beraberinde getirmiştir. Menkul olmasından dolayı vakfedilip vakfedilemeyeceği, para üzerinden elde edilen gelirlerde faizli işlemler ile karşılaşma riski gibi hususlar ve tartışmalar para vakıflarının kurulmasının dini temellere oturmasını sağlamış, para vakıflarında kurucuların ve mütevellinin faiz hassasiyeti de bu vakıflardaki para kullandırma şekillerinde modern faizsiz finans kurumlarının öncüsü olarak nitelenebilecek uygulamaların gelişmesini sağlamıştır. Dolayısı ile para vakıflarını ve uygulamalarını iyi anlamak için müçtehit imamların görüşleri ile birlikte Osmanlı ulemasının bu konudaki tartışmalarının temel meselelerini bilmek ve bu görüş ile tartışmalar ışığında vakfın kuruluş sürecini ve denetimini anlamak açısından önemlidir.

\section{Para Vakıflarının Dini Temelleri ve Tarihi}

Osmanlılar da diğer İslâm toplumları gibi ekonomik ve sosyal uygulamalar için dini dayanak aramıştır. Para vakıflarının kurulması ve işleyişi aynı şekilde müçtehit imamların görüşlerine dayandırılmış ve para vakıflarının kuruluşu için ulemadan cevaz alınmıştır. Hatta para vakıflarının caiz olması ile ilgili bu durum Behcetü'l-Fetâva'nın Kitabu'l-Hudûd kısmında, "bir alim eğer 'para vakfi haramdır, para vakfedenler cehennemliktir ve bu paradan hasıl olan gelir haramdır, onu yiyen imama uyulmaz' derse ve bu yüzden para vakfi sayesinde ayakta kalan yani para vakfının finanse ettiği mescitlerin boşalmasına yol açar ve insanlar arasında fitneye sebep olursa bu alimin şerî hükmü önce şiddetli şekilde uyarılması, bu sözlerinden dönmediği takdirde dönünceye kadar hapis edilmesi gerektiği” şeklinde yer almaktadır (Şeyhülislam Yenişehirli Abdullah Efendi, 2011, s. 163). Osmanlı uleması para vakıflarına cevaz verirken Osmanlıların resmi mezhebi olarak Hanefi müçtehit imamların görüşlerini esas almıştır.

Bazı vakfiyelerde para vakıflarının hangi usullere göre caiz kabul edildiği detaylı olarak tarif edilmiştir. Vakfiyelerde, Hanefi müçtehit imamların, İmâm Azam Ebu Hanife, İmam Muhammed, İmam Ebu Yusuf, İmam Züfer, görüşlerine atıflar yapılmıştır. İmam Ebu Hanife gayrimenkul malların vakfedilmesine izin verirken menkul malların vakfedilmesine izin vermemiştir. Menkul malların tek başına vakfedilmesinin vakfın temel şartlarından birisi olan kalıcılık ilkesiyle çeliştiğini söylemiştir. Fakat onun İslâmî finansman yöntemlerinden mudarebe ve murabaha gibi uygulamalara verdi- 
ği izin ve ticaret konusundaki fetvaları (Sıddıki, 1982, ss. 5-6) para vakıflarının borç verirken uyguladığı finansal yöntemlere 1şık tutmuştur. Bu sebeple para vakıfları kurulmasına izin verilmesi konusunda görüşler İmam Ebu Hanife'ye değil onun öğrencileri İmam Züfer ve İmameyn (iki imam) olarak kabul edilen İmam Muhammed ve İmam Ebu Yusuf a dayandırılmaktadır. İmameyn'in ortak görüşü, İmam Ebu Hanife ile çeliştiğinde İmameyn'in görüşü geçerli kabul edilmektedir. İmam Ebu Yusuf da aslında hocası İmam Ebu Hanife gibi taşınabilir malların vakfedilmesine karşıydı. Sadece özel savaş durumlarında at, silah vb. malların vakfedilebileceğini söylemekteydi. İmam Muhammed ise eğer menkul malın vakfedilmesiyle ilgili bir teamül oluşmuşsa bunun caiz olacağını söylemiştir. Gayrimenkul mallar ile birlikte vakfedilen menkul malların ise caiz olduğu konusunda İmameyn'in ortak hükmü bulunmaktadır. Para vakıflarını mutlak olarak caiz gören imam ise İmam Züfer'dir. İmam Züfer ayrıca vakfedilen paradan nasıl gelir elde edilebileceğini de açıklamıştır. İmam Züfer'in görüşünün öğrencisi İmam Ensarî'den nakledildiği de yine vakfiyelerde karşımıza çıkmaktadır (Kudat, 2015, ss. 62-64).

İslâm uleması arasında görüş farklılıklarına sebep olan menkul malların vakfedilmesi hususu Osmanlılarda da tartışılmıştır. Para vakıflarının caizliği ile ilgili ilk yazıyı İbn Kemal (Ö: 1534) kaleme almıştır. Şeyhülislâmlık da yapan İbn Kemal yazdığı risale ile para vakıfları ile ilgili olumlu görüşünü özetlemiştir. Bu risale, para vakıfları ile ilgili görüş bildirmesi açısından bu konuda başlayacak tartışmaların öncüsü ve habercidisidir. İbn Kemal'den sonra Çivizade Mehmed Muhyiddin Efendi (Ö: 1547) para vakıflarının caiz olmadığı yönünde hareket etmiş ve para vakıflarının 3 yıl gibi bir süre $\mathrm{Ru}-$ meli'de yasaklanmasını sağlamıştır. Bu yasak süresince Rumeli'de özellikle para vakıfları tarafindan finanse edilen cami vb. kurumlar maddi zorluklar çekmiş ve hayırseverler de bu dönemde para vakfetmekten beri durmuştur. Bu yasağın yol açtığı sorunlar ile ilgili olarak Bali Efendi gerek Çivizade'ye gerekse de dönemin padişahına mektuplar yazmıştır. Yasağın kalkmasında bu mektupların da etkisi vardır. Osmanlıların en önemli şeyhülislâmlarından biri olan Ebussuûd Efendi'nin (Ö: 1574) para vakıfları ile ilgili görüşleri para vakıflarının Osmanlılarda yaygınlaşmasında önemli role sahip olmuştur. Ebussuûd Efendi, para vakıflarının cevazına hükmetmiştir. Para vakıfları konusunda faizli işlemlere yol açtığı yönünde görüşleri ile Birgivi Mehmed Efendi (Ö: 1573) para vakıflarının meşru olmadığını beyan etmiştir. Fakat 
genel olarak incelendiğinde dönemin diğer uleması para vakıflarının meşruiyetleri yönünde görüş bildirmişlerdir (Özcan, 2000, ss. 31-32).

Para vakıflarının yaygınlaşması ve Batı'daki faizli finans kuruluşlarına alternatif oluşturması her ne kadar Osmanlılar döneminde olmuş olsa da bu dönemlerden önce para vakıfları uygulamaları ile karşılaşıldığı görülmektdir. Seyyid Abdülmecid (1910) eserinde bu durumu al-Menah'ta ve diyâr-1 Rum'da dirhem ve dinarın vakfedilmesi adetinin bulunduğunu ve bu vakıfların halkın arasında alışveriş işlerinde kullanıldığını söylemektedir. Ayrıca bütün menkul malların vakfedilebileceğine dair fetvanın da Ebu Muhammed tarafından konan kurala dayandığı belirtilmiştir. Dirhem ve dinar vakfedilmesinin meşruiyeti ve sıhhati konusunda İmam Ensâri'nin rivayeti ve İmam Züfer'in hükmü yanında Mevlâna da dirhem ve dinar vakfina dair fetva vermiştir. Remli'nin de bu konuda fikir ve mütalaası vardır ve yolcular ile misafirlere süt dağıtmak için inek vakfedilmesi bu durumun adet olduğu yerlerde meşru ve caiz görülmüsstür. Bunun yanında Ensâri'ye dirhemle tartılıp ölçülebilen malların vakfedilmesinin caiz olup olmadığı sorulduğunda buna cevaz verilmiştir (Seyyid, 1910/1328, s. 162; aktaran Çağatay, 1969, ss. 49-50).

Osmanlı döneminde bilinen ilk para vakfı 1423 tarihinde ${ }^{1}$ Hacı Muslihuddin (Semmân) bin Halil Vakfi'dır. Edirne'de Kilise-Câmii Mahallesi'nde kurulan bu vakıf için kurucu Yağcı Hacı Muslihuddin 10.000 akçe ve Ağaçpazarı'nda bulunan dükkanları vakfetmiştir. Vakfedilen nakit paranın yıllık geliri 1.000 akçe olarak yazıldığı için yıllık borçlanma maliyetinin yüzde on olarak belirlendiği çıkarımı yapılabilir (Gökbilgin, 1952, ss. 272-273). Osmanlıların ekonomik ve sosyal hayatına büyük etkisi olan para vakıfları uzun yıllar nakit ihtiyacı olan girişimcilere kaynak sağlamıştır. Buradan gelen kârlar ise vakfın amaçları doğrultusunda harcanmıştır.

\section{Para Vakıflarının Kuruluș Süreci ve Denetimi}

Bir akit olarak düşünebileceğimiz para vakıflarında da akitlerde aranan bağlayıcı olma, geçerli olma, meydana gelme ve yürürlük kazanma şartları aranır. Bağlayıcı olma lüzum şartı, geçerli olma sıhhat şartı, meydana gelme in 'ikad şartı ve yürürlük kazanma ise nefâz şartıdır. Eğer akit bu dört temel şart üzerine inşa edilirse bireyler arasındaki anlaşmazlıkla önlenmiş olur. $\mathrm{Bu}$ şartlar ışığında Şeyhülislâm Ebussuûd Efendi para vakıflarına cevaz verirken İmam Muhammed'in teamül esasını ön plana almış ama teamül esasına yö-

1 Gökbilgin (1952) kitabında bu tarihe [11.V.1423] şeklinde yer vermiştir. 
nelik eleştiriler için de uygulamalarda İmam Züfer'in görüşünü esas almıştır (Kudat, 2015, ss. 65-66). Para vakıfları kurulurken bu şartlar ve müçtehitlerin görüşleri ön plana alınmıştır. Ebussuûd, para vakıflarına cevaz verirken kuruluş prosedürünü de göstermiştir. Para vakıflarını sahih gören fakat lüzum şartını aramayan İmam Züfer'in görüşü ile sıhhat ve lüzum şartlarının birbirinden ayrı görülemeyeceğini ifade eden İmameyn'in görüşleri birbiri ile bağlanmış ve para vakıflarının kuruluşuna izin verilmesiyle Osmanlı dünyasında yayılması hız kazanmıştır.

Vakfın geçerlilik ve işlerlik kazanması ise tescile bağlıdır. Vakfın tescilini kadı yapmaktadır. Kadının vakfın kurulmasının lüzumuna onay verilmesiyle vakıf tescil olunmaktadır. Bu süreç vakıf kurmak isteyenin yazdırmış olduğu vakfiye ile kadıya gelmesiyle gerçekleşmektedir. Vakfın kurulma sürecini iki kısma ayırabiliriz. İlk kısım hayırseverin parayı vakfetmesi ve daha sonra İmam Ebu Hanife'ye göre menkul vakfedilmesi gayr-i lâzım olduğu içinden bundan vazgeçmesi olarak gerçekleşmektedir. Daha sonra ikinci kısım olan mütevellinin itirazı ve vakfin müçtehit imamların görüşlerine göre tasdik kısmı gerçekleşmektedir.

\section{Șekil 1. Para Vakfı Kuruluș Süreci}

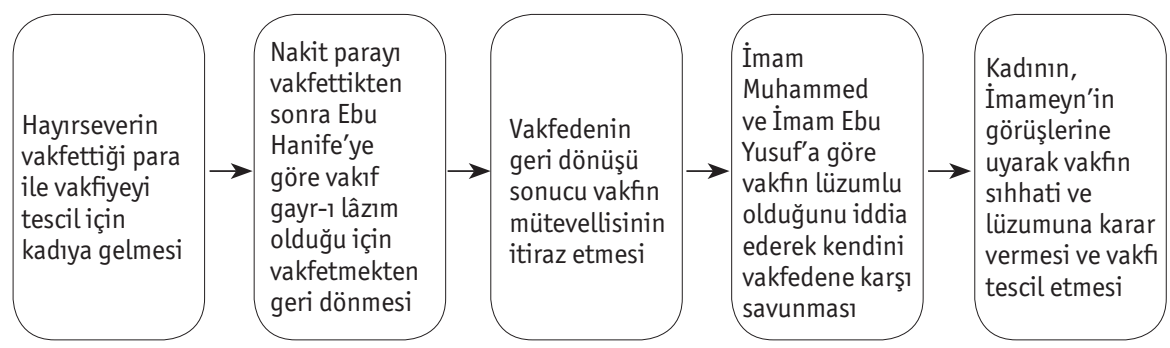

Para vakıfları denetim konusunda oldukça sıkı bir denetime tabiydi. Kurulurken kadıya onaylattırılan vakıfların işleyiş süreçleri de vakfa nezaret eden kişiler ve özellikle büyük vakıflarda muhasebeciler tarafindan denetlenmekteydi. Vakıftan borç kullananlardan ipotek ve/veya kefil talep edilmesi de vakfın sürekliliğini sağlamak amacı güden bir uygulama idi. Ayrıca kötü niyetlilere firsat vermemek için vakfin mütevellisinin borç verilecek kişiye kefil olmasının da fetvalar ile önüne geçilmişti².

2 Zeyd mütevellisi olduğu para vakfindan kârını almak üzere borç verdiği Amr'a bu borç için kefil olsa kefalet geçerli olur mu? Cevap: Olmaz (Şeyhülislam Yenişehirli Abdullah Efendi, 2011, s. 338) 


\section{FAIZSIZ FINANSIN ÖNCÜSÜ OLARAK PARA VAKIFLARI}

Sermaye sahiplerinin sermayelerini değerlendirme isteği ve üretmek, ticaret yani iş yapmak isteyenlerin de nakit ihtiyacı her zaman geçerli bir husustur. Bu husus paranın da bir zaman değeri oluşmasına sebep olmuş ve bu değer faiz olarak tanımlanmıştır. Bazı medeniyetlerin kanunlar ile (Hamurabi kanunları, Roma Hukuku) düzenlenen faiz uygulaması ilahî dinlerde ise yasaklanmıştır. Arap Yarımadası'nda 7. yüzyılda yaygın olan birbirinin aynısı olan veya benzer ürünlerin birbirleri ile değişimi anlamına gelen riba-i fadl ve günümüzde tefecilik olarak da tanımlanabilecek borçtan faiz almak ve ödenmemesinde müddeti uzatmak ve faizi de fahiş olarak artırmak olan riba-i nesie yani borca faiz işletme metotları İslâm'da faiz yasağının gelmesiyle yasaklanmıştır (Çağatay, 1969, ss. 39-40). Her ne kadar yasağın sadece riba-i nesie yani yüksek faiz ve tefecilik ile ilgili olduğunu söyleyen alimler olsa da genel görüş faiz yasağının bu iki türü de kapsadığı yönündedir. Dolayısıyla bu kısıtlar altında İslâm ekonomisi, finansı ve borçlanma hususunda para üzerinden para kazanmayı değil de emeğe, üretime ve ticarete dayanan bir ekonomik model inşasını öngörmektedir.

\section{Para Vakıflarının Fonksiyonları ve Önemi}

Para vakıfları da diğer vakıflar gibi önceden belirlenmiş bir hayır hizmeti amacıyla kurulurlar. Altyapı hizmetlerinin giderlerinin karşılanması, dini hizmetlerin devamının sağlanması, eğitimin finansmanı vb. diğer amaçlar ile kurulan para vakıfları toplumun ekonomik ve sosyal ihtiyaçlarının karşılanmasında önemli bir işlev görmektedir. Vakıflar finanse ettikleri bu kurumların uzun yıllar ayakta kalmasını sağlamışlar ve günümüze bu eserlerin aktarılmasını sağlamıştır. Vakıfların finansmanı sayesinde Osmanlı ve İslâm kültürüne ait kitaplar, mimari eserler, altyapı yatırımları sonraki kuşaklara aktarılabilmiştir.

Para vakıfları iki yönlü fayda sağlayan kurumlardır. Vakıfların gelirleri vakfın amaçlarında harcandığı gibi vakıfın gelir kaynağı olan faaliyetler de nakit ihtiyacı olan girişimciler için faizsiz finansman imkânı sunmuştur. Para vakıfları ayrıca girişimcilerin yüksek faizle borç veren tefecilerden korunmasını sağlamış ve tefecilik kurumunun oluşmasını önlemiştir.

Para vakıflarının bir diğer önemli fonksiyonu uzun yıllar piyasada ortalama borçlanma maliyetinin belirli olmasından ötürü sağlanan finansal istikrardır. Para vakıflarında uygulanan borçlanma oranının önceden vakfiyeler ile tespit edilmesi ve bu oranın üst limitinin kanun ile tespiti piyasadaki 
borçlanma oranları üzerinde bir dengeleme mekanizması kurmuş ve piyasa için bir belirleyici unsur olmuştur. Dolayısı ile para vakıfları Osmanlılardaki finansal istikrarın temel unsuru olarak faaliyetlerini sürdürmüştür. Para vakıflarının borçlanma maliyetlerinin uzun yıllar değişmemesi sayesinde Osmanlı esnaf, girişimci ve tüccarları piyasada borç bulacakları oranı önceden öngörebilmiş ve daha istikrarlı bir yatırım ortamının sağlanmasını sağlamıştır (Bulut \& Korkut, 2016).

Para vakıfları gayrimenkul vakıflarına nazaran kurulum açısından işlem maliyetleri daha düşük olan vakıflardır. Ayrıca dönemin gayrimenkul kiraları ile kıyaslandığında vakfedilen paranın satın alabileceği değerde bir gayrimenkulün kira getirisi ile para vakfında İslâm usul ve yöntemlere göre işletilen paranın kâr ve getirisi yanında daha düşük kalmaktadır. Dolayısı ile gayrimenkulün harap olma riski ve bakım giderleri, getirisinin nispeten düşük olması, işlem maliyetlerinin daha yüksek olması gibi sebepler hayırseverlerin para vakfi kurmaya sevk eden nedenlerden bazılarıdır.

\section{Para Vakıfları ve Finansman}

Modern İslâmî finans metotlarının öncüsü olan uygulamalar ile borç veren para vakıfları ile ilgili olarak vakfiyelerde genellikle irbah, istiğlal, istirbah, muamele-i şer'iyye gibi terimlere yer verilmiştir. Paradan gelir elde edilmesi manasına gelen bu terimler, borç maliyeti oranı, borç verilecek kişiden talep edilecek hususlar vakfiyelerde yer alan diğer hususlardır. Para vakıflarında uygulanan işletilme usulleri (1) Akara tebdil, (2) bey ${ }^{6} i$ istiğlâl, (3) bidâa, (4) Evkāf-1 Hümayûn Beytülmal Kassamlığında nemalandırma, (5) karz, (6) Kısmet-i Askeriyye Mahkemesinde istirbah, (7) mudarebe, (8) murabaha olarak sıralanabilir (Çam, 2014, s. 40).

Para vakıflarının kuruluş amaçlarını yerine getirmesini sağlayan bu yöntemler ile vakıflar işleyişini sürdürebilmiştir. İşlem maliyetlerini aza indirmek için bir nevi ipotekli satış yahut borçlanma olan bey'i istiğlâl metodunun çok kullanılmasına rağmen mudarebe gibi metotlar da para vakıflarında kullanılan, ticaret ve üretimi finanse eden önemli metotlardır.

Aynı şekilde örneklerde de görüleceği üzere vakıfların yapacağı işlemler açısından sınırlarını belirleyen vakfiyelerde mu'âmele-i şer'iyye terimi de kullanılmaktadır. Mu'âmele Hz. Peygamber döneminde ziraat ortakçıllı̆̆ ve sonraki dönemlerde mudarebe işlemleri için kullanıldığı gibi alım-satım manasına da gelmektedir. Bu terim mu'âmele-i şer'iyye şeklinde kullanıldı- 
ğında İslâm dininin emir ve yasakları çerçevesinde yapılacak ticari işlemler olduğu anlaşılabilir. Bunun yanında Döndüren (1992) mu'âmele-i şer'iyye kavramının iyne satışı için yani malı veresiye pahalı satıp peşin parayla daha ucuza alma şeklinde gerçekleştiğini de söylemektedir. Ticari işlemlerde (mu'âmele) rıbh terimi kâr manasına gelmekte olup eğer bu ticari işlemde rıbhtan söz edilmeyecek ise bu işlemlerin karz-ı hasene döneceği açıktır. O halde para vakıflarında mu'âmele-i şer'iyye vakıf paranın yani vakfın sermayesinin İslâmî ölçüler ile kullanılmasıdır (Döndüren, 1992, ss. 19-20).

\section{Para Vakıflarında Ortaklıklar}

Para vakıflarında ortaklık modellerinin kullanıldı̆̆ına dair vakfiyelerde mudarebe ve muşareke terimleri geçmemekle beraber bazı vakfiyelerde vakıftan borç kullanacak kişinin özellikleri tarif edilirken özellikle ehl-i tüccar ve ehl-i sanayi vurguları vakıftan verilecek borcun ticaret ve üretim faaliyetleri yapanlara verilmesi gerektiğini göstermektedir. Ayrıca özellikle sabit geliri olan memur, ulema gibi meslek sahiplerine borç verilmemesi kuralı da para vakıflarının tüketici kredisi gibi sadece nakit borca dayanan bir borç vermediğinin göstergesidir.

Örneğin 1741 tarihli Yunanistan'da kurulmuş olan Ahmed Efendi bin Mustafa Ağa $\mathrm{Vakfi}^{3} 252.000$ akçe sermayeye sahiptir. İşletim oranı olarak $\% 15^{4}$ olarak belirlenmiştir. Vakıftan borç kullanacakların iflas eden, kötü niyetli, borcunu bilerek geciktiren kişilerden seçilmemesi, Osmanlı tebaasından tüccar ve sanayi ehline verilmesi vakfiyede bildirilen şartlardandır. Ayrıca borç kullanacak kişilerin o yöreden seçilmesi de vakfiyede yer almaktadır ${ }^{5}$. Aynı hayırseverin yine aynı yerde kurduğu 26 Nisan 1742 tarihli vakıfta $^{6}$ da

3 Vakıflar Genel Müdürlüğü Arşivi (VGMA), Defter No: 624, Sayfa: 315, Sıra: 285, Gurre-i Rebiülevvel 1154 / 17 Mayıs 1741

4 Bu oran vakfiye metninde onu on bir buçuk hesâbı olarak yer almaktadır.

5 “...Zikri sebk iden iki yüz elli iki bin akçe senevî onu on bir buçuk hesâbı üzere istirbâh olunub bi-fazli'llâhi te‘âlâ hâsıl olan gallesi masânf-ı âtiyeye sarf oluna ammâ mütevellî meblağ-ı mesfûr müflisîn ve eşrâr ve za'îfü'l-hâl ile mu‘âmeleden ihtirâz idüb takallüb ve mumâtale ashâbına virmeyüb mevsûkun bih ve mu'temedin aleyh tüccâr-ı zevi'l-iktidâra ve ra'iyyet ve ehl-i sanâyi'den hüsn-i mu‘âmele ile sâhib-i iştihâr olan ehl-i servet-i dinâra rehn-i kavî ve kefíl-i ganî veyâ ehâduhumâ ile ber-zimmet idüb re's-i senede tecdîd-i mu'âmele ve iştihâd-ı tescîle taksîr itmeye şöyle ki; Bu bâbda müsâmahası zâhir olur ise bi-hesâb- şer'î illet-i taksîr ra'iyye tazammun ola ve Medîne-i Tırhala varoşunda ve kazâsında sâkinîn ehl-i zimmet-i kefere re ‘âyalanı veyâ taraflarından vekîlleri olan kocabaşıları meblağ-ı mevkūf-ı mezkûru onu on bir buçuk hesâbı ile der-zimmete tâlib olduklannda merkūmûna virilüb âhardan bir ferde virilmeye..."

6 Vakıflar Genel Müdürlüğü Arşivi (VGMA), Defter No: 625, Sayfa: 124-125, Sıra: 129, 20 Safer 1155 / 26 Nisan 1742 
aynı şekilde 252.000 akçe vakfedilmiş ve vakıftan tüccarların ve sanayi ehlinin borç alması şartı konulmuştur. Çalışmada bahsi geçen diğer örneklerde de vakıf kurucusu vakfiyede, vakıftan borç kullanacak kişilerin tüccarlar olacağı şartına yer vermiştir.

Sanayi ve ticaret vurgusu para vakıflarının tüketim ürünleri finansmanı değil ticaret ve üretime yönelik ekonomiye katma değer sağlayan yatırımların finansmanını sağladıklarının göstergesidir.

\section{Rıbh ve Faiz}

Osmanlı İmparatorluğu'nda, toplumun yapısı ve toprak sistemi, insanların birbirleri arasındaki ilişkilerin güçlü olmasını sağlamış ve bu sayede borç-alacak ilişkileri para vakıfları vasıtasıyla, ortaklaşa kurularak ödeme yapılan sandıklardan ve fetvalar ile kadı sicillerinden anlaşılacağı üzere bireysel olarak iki kişi arasında gerçekleşmiştir. Bu ilişki gerçekleşirken üzerinde durulan husus ise İslâm'da yasaklanan faiz riskinden uzak durulmasıdır. Faizli işlemlerde bulunmak en kötü günahlardan biri olarak kabul edilmiştir ve sadece zorunluluk hallerinde faize izin verilmiştir. Dolayısıyla para vakıflarında İslâm'a göre faiz kabul edilecek işlemlerden kaçınılmıştır. Uygulanan metotlar özellikle bir emek-sermaye ortaklığına veya mal ticaretine dayandırılmaya çalışılmıştır. Vakfiyelerde bu durum özellikle borç verilirken helâl kabul edilen yöntemlerin uygulanması şartı koşularak belirtilmiştir.

Para vakıfları ile ilgili diğer bir husus ise hayırseverin parayı vakfettikten sonra bu paranın getirisinden bir beklentisi olmamasıdır. Dolayısı ile paranın işletilmesiyle bir gelir beklentisi olmadığı için para vakıflarında aşırı kâr iştahı yoktur. Mütevelliler gibi bağımsız yöneticilerin kontrolünde olan ve denetlenen vakıflar paranın işletilip gelir elde edilmesinde kendilerine vakfiyelerde çizilen alanın içinde kalmış, faiz geliri değil rıbh olarak tanımlanan ve helâl usullerden elde edilen geliri vakfın amaçları doğrultusunda kullanmiştır.

Faizli işlemler başkalarının zararından doğan kazançlardır. Risksiz kazanç olarak da tanımlayabileceğimiz faizin üretim ile hiçbir ilişkisi bulunmamaktadır. Yani borç alanın ticaret veya üretimden ettiği zarar borç vereni bağlamamakta, vermiş olduğu parayı faizi ile birlikte geri alabilmektedir. Bu durumda da sermaye sahipleri sürekli kazanıp, servetlerini büyütebilirken asıl reel iktisadi faaliyeti yapan tüccar yahut üreticinin durumu kötüye gitmektedir. Bu durumda zamanla sermaye sahipleri iktisadi pazara hâkim olmakta ve 
tekelleşme doğmaktadır. Üretimi baltalayan bu gelişmeler bir dönem sonra istihdamı da azaltmakta ve insanlar kâr elde etmek için ticarete yahut üretime değil faiz gelirine yönelmektedir. İktisadi açıdan asıl olan üretmek ise bu yöneliş sağlıklı sonuçlar doğurmamaktadır. Kredi sisteminin emek-sermaye ortaklığı değil de tüketim odaklı yahut direkt olarak para üzerinden para odaklı olarak kurulması sistemin bir süre sonra krizler doğurmasına sebep olacaktır (Sayı, 1987, ss. 35-37)

Rıbh denilen kazançta ise genellikle bu konu üzerinde durulmaya çalışılmıs. Ticaret yahut üretim bölgesel olarak finanse edilmeye çalışılmışır. Çalışma kapsamında incelenen örnek para vakıflarında görüleceği üzere genellikle sanayi ve ticaret ehline borç verilmesi tavsiye edilmiş, sabit geliri olanlara borç verilmesinden kaçınılması söylenmiştir. Ayrıca borç alanların borçlarını ödemedikleri takdirde aşırı şekilde zorlanmaması gerektiği de vakfiyelerde bahsi geçen hususlardan birisidir.

\section{ÖRNEK PARA VAKIFLARI}

Para vakıfları ile ilgili bilgi edinmek için incelenebilecek birincil kaynaklar vakfın kuruluş belgesi yani vakfiyesi, vakıf tahrirleri, vakıf muhasebe defterleri ve şer‘̂̂yye sicilleri olarak sıralanabilir. Çalışmanın bu bölümünde Vakıflar Genel Müdürlüğü Arşivi’ndeki ve şer‘îyye sicillerindeki vakıfların kuruluş belgeleri olan vakfiyeler incelenecektir.

Genel olarak bir vakfiyede vakıfların kurucusu, kurulduğu yer, vakfı yönetecek kişi (mütevelli), vakfedilen mallar ve nakit para miktarı, vakfedilen paranın işletilme yöntemi ve işletim oranı, vakfın gelirlerinin verileceği kaynaklar (cami, medrese gibi yerlerin ihtiyaçları, çalışan ücretleri gibi), vakfın kuruluş ve tescil tarihi, son kısımda her vakfiyede olmasa da Bakara Suresi'nin 181. ayeti ve en sonda da şahitlerin isimleri bulunur. Vakıfların kuruldukları ve faaliyette oldukları dönemde finansal, iktisadi ve sosyal hayata yönelik bilgiler veren vakfiyelerin incelenmesi bu açıdan önem arz etmektedir. Çalışmada bahsedilen örneklerden görüleceği üzere para vakıfları tüketimden ziyade üretimi finanse etmeyi gaye edinmiştir. Bu sebeple tüccarlara borç verilmesi vakfiyelerde özellikle vurgulanan hususlardır. Ayrıca sabit ücretli kimselere borç verilmemesi şartı da tüketim odaklı bir finansmandan uzak durulduğunun göstergesidir. Rumeli'nin çeşitli bölgelerinden (Bulgaristan, Edirne, Romanya ve Yunanistan) ve çeşitli yıllardan (1678, 1696, 1723 ve 
1902) alınan vakfiye örneklerinde görüleceği üzere işletim oranı diğer vakfiyelerde de genellikle yüzde 15 (onu on bir buçuk) olarak zikredilmektedir.

Para vakfı kurmak için yönetici yani asker sınıfına ait olma şartı bulunmamaktadır. Reaya denilen normal halk da elindeki ufak birikimleri ile tek başına yahut bir araya gelerek para vakıfları kurabilmiş ve bulundukları yörede hizmet gösteren cami, medrese, mescit vb. faaliyetlerin devamını sağlamıstırlar.

\section{Harita 1. 19. Yüzyıl Bașında Osmanlılar Yönetimi Altındaki Balkan Toprakları}

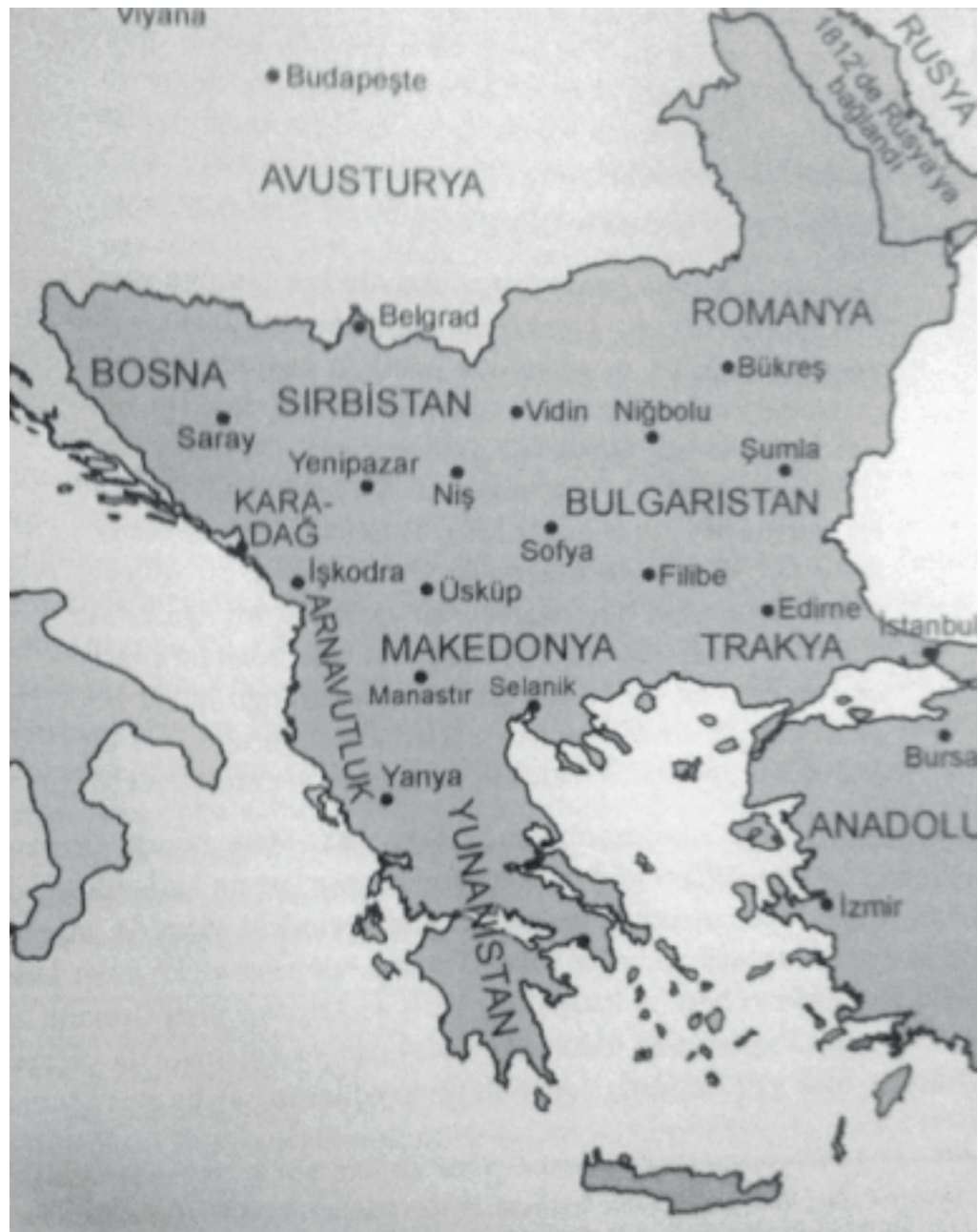




\section{Hacı Murtaza Çelebi bin Hacı Ahmed Vakfı ${ }^{7}$}

Hacı Murtaza Çelebi bin Hacı Ahmed Vakfi, günümüzde Bulgaristan sınırları içerisinde kalan ve Osmanlılar tarafından 1393 yılında fethedilen Tırnova/Tırnovo Şehri Hızır Bey Mahallesi’nden Hacı Ahmed oğlu Merhum Hacı Murtaza Çelebi'nin ölümünden sonra vasiyeti ile 1678 yılında kurulmuştur. Vasiyetini damadı Mehmed Ağa bin Hasan Bey vakfın mütevellisi olarak atanan vasiyet sahibinin oğlu Hacı Mehmed Çelebi'nin şahitliğinde yerine getirmiştir. Vakfedilen 1.000 kuruş için riba/faiz aldatmacasından ve şeriata aykırı anlaşmalardan kaçınılarak, yıllık yüzde 15 oranıyla istiğlal ve istirbah edilmesi şartı vakfiyede yer almaktadır ${ }^{8}$. Vakıf paranın geliri ise Tırnova'daki cami ve medrese görevli ücretleri, Kur'an-1 Kerim kıraat edilmesi, mütevelli ücreti ve kurucunun yaptırmış olduğu taş yolun tamiri için ayrılmıştır. Bunun yanında Aziz Mahmud Hüdayi Hazretlerine ${ }^{9}$ tabilerine de yapacakları hizmetler karşılığında ödenecek ücretler vakfiyede yer almaktadır. $\mathrm{Bu}$ vakfiyede ayrıca vakıf paradan gelen gelir ile buzhaneden buz alınarak kâr ile satılması ve gelen gelirle Ramazan ayı sonunda, bayramda yoksullara giysi alınması şartı bulunmaktadır. Vakıf paranın kullandırma şartları ile ilgili olarak da kurucu mütevelli olarak belirlediği oğlu için şartlar sunmuş, oğlundan görevini layıkıyla yapmasını, borç verdiği kişileri borç istemek için vakitli vakitsiz rencide ve taciz etmemesini, ticaret ehli iktisadi anlamda sağlam tüccarlar ile aynı bölgede sakin olan namuslu kişilere güvenilir bir kefil ve ipotek karşılığında vakıf paradan vermesini aksi halde vermemesini belirtmiştir ${ }^{10}$. Vakfiyede müçtehit imamların görüşlerine, Bakara Suresi 181. ayete, tescil tarihine ve şahitlere de yer verilmiştir.

\section{İbrahim Efendi bin Hacı Suphi Vakfı ${ }^{11}$}

İbrahim Efendi bin Hacı Suphi Vakfi, Edirne'nin Turgut Bezirgan Mahallesi'nden Hacı Suphi oğlu İbrahim Efendi tarafından 1696 yılında 5.000

7 Vakıflar Genel Müdürlüğü Arşivi (VGMA), Defter No: 987, Sayfa: 193, Sıra: 62, 27 Zilhicce 1088 / 20 Şubat 1678

8 “... meblağ-ı mevkūf- ו mezkûru alâ-vechi'l-mu'tâd ve'l-mübâh beyne'n-nâs istiğlâlde istirbâh eyleyüb mugāalâta-i ribâ ve muhâlata-i riyâdan ihtirâz olunub bi-fazli'llâhi'l-Kerîmi'l-vehhâb onu on bir buçuk hesâbından her senesinde ..."

9 Vakfiyede Üsküdâri Mahmud Efendi olarak yer almaktadır.

10 “... oğlum mezbûr el-Hâc Mehmed mütevellî olub mârru'z-zikir yirmi guruşa mutasarnf ola ammâ vazî́fem kalîldir ve hizmetim kesîrdir dimeye ve vakitli vakitsiz zimem eylediği ibâdu'llâhı rencîde ve ta'cîz itmeye ve erbâb-ı tüccâr-ı zevi'l-iktidâr ve mütemekkin-i fi'l-emsâr ve ehl-i ırz sâhib-i vakār ile mu'âmele olunub ve rehn-i kavî ve kefíl-i melî yâhûd mahall-i zarûretde ikisinden biri olmayınca bir ferde akçe ve mâl-ı vakf virilmeye ..."

11 Edirne Şer‘iyye Sicili, 05267.00002, 3 Cemaziyelahir 1108 / 28 Aralık 1696 
kuruş vakfedilerek kurulmuştur. Vakıf paranın işletim oranı olarak istiğlal ve istirbah edilmek üzere yıllık yüzde 15 belirlenmiştir. Vakfin geliri ise çeşitli hayır hizmetlerinin yanında Kadı Bedreddin Camii, Defterdar Camii, Turgut Bezirgan Camii, Papasoğlu Mescidi, Ayşe Hatun Camii, Kap1 Camii giderleri ve görevlileri ücretlerine ayrılmıştır. Bu vakfiyede vakıftan borç kullanabilecek kişiler detaylı şekilde tarif edilmiştir. Özellikle dürüst ve iktisadi anlamda güçlü tüccarlara borç verilmesi, faizli işlemlerden kaçınılması, iflas eden yani maddi durumu olmayan kişiler ile kadı, müderris, asker ve diğer kamu görevlilerine borç verilmemesi, borç verilirken güvenilir ve salih bir kefil istenmesi de şartlar arasında yer almaktadır. Bunun yanında borç ödenirken verilebilecek hurda ve zayıf akçelerin alınmaması ve bir nevi operasyon ücretleri denebilecek kalemiye gibi masraflar konusunda da borç alandan herhangi bir şey talep edilmemesi vurgulanmıştır. Vakfiyede müçtehit imamların görüşlerine, Bakara Suresi 181. ayete, tescil tarihine ve son kısımda ise şahitlerin isimlerine yer verilmiştir.

\section{Ahmed Ağa ibn İsmail Vakfı ${ }^{12}$}

Ahmed Ağa ibn İsmail Vakfi, İstanbul'da ikamet eden ve Sultan Beyazıd Han vakfının mütevellisi İsmail oğlu Ahmed Ağa tarafindan 1723 yılında kurulmuştur. Vakıf kurucusunu İsmail oğlu Ahmed Ağa mütevelli olarak tescil için Hasan Ağa ibn Abdulfettah'1 görevlendirmiş ve onun şahitliğinde vakfettiği parayı zikretmiştir. Kurucu, günümüzde Romanya'nın Dobruca bölgesinde bulunan Babadağ Kasabası Kara Nasuh Mahallesi’nde harap olan caminin, üstte cami altında da 3 dükkân ve 2 mahzen ile yeniden inşa edildikten sonra 300 kuruş nakit parasını bu caminin görevlileri (imam, hatip, müezzin, devirhan), camide Kur'an-1 Kerim okuması ve vakıf mütevelli ücreti için vakfetmiştir. Vakıf paranın işletim oranı ise mu'âmele-i şer'iyye ve murâbaha-i mer'iyye ile yıllık yüzde 15 (onu on bir buçuk) olarak belirlenmiştir. Vakıf paranın mütevelli eli ile istirbâh ve istiğlâl olunması ve güvenilir bir kefil ve sağlam bir ipotek gösteren iktisadi anlamda güçlü tüccarlara verilmesi şartı koşulmuştur. Vakfin son kısmında ise vakfın İslâmî usul ve esaslara göre müçtehit imamların görüşleri ışığında yasallaştırılması, tescil tarihi ve şahitlerin isimleri yer almaktadır.

12 Vakıflar Genel Müdürlüğü Arşivi (VGMA), Defter No: 734, Sayfa: 293, Sıra: 147, 21 Safer 1136 / 20 Kasım 1723 


\section{Fotoğraf 1. Babadağ - Romanya 19. Yüzyıl}

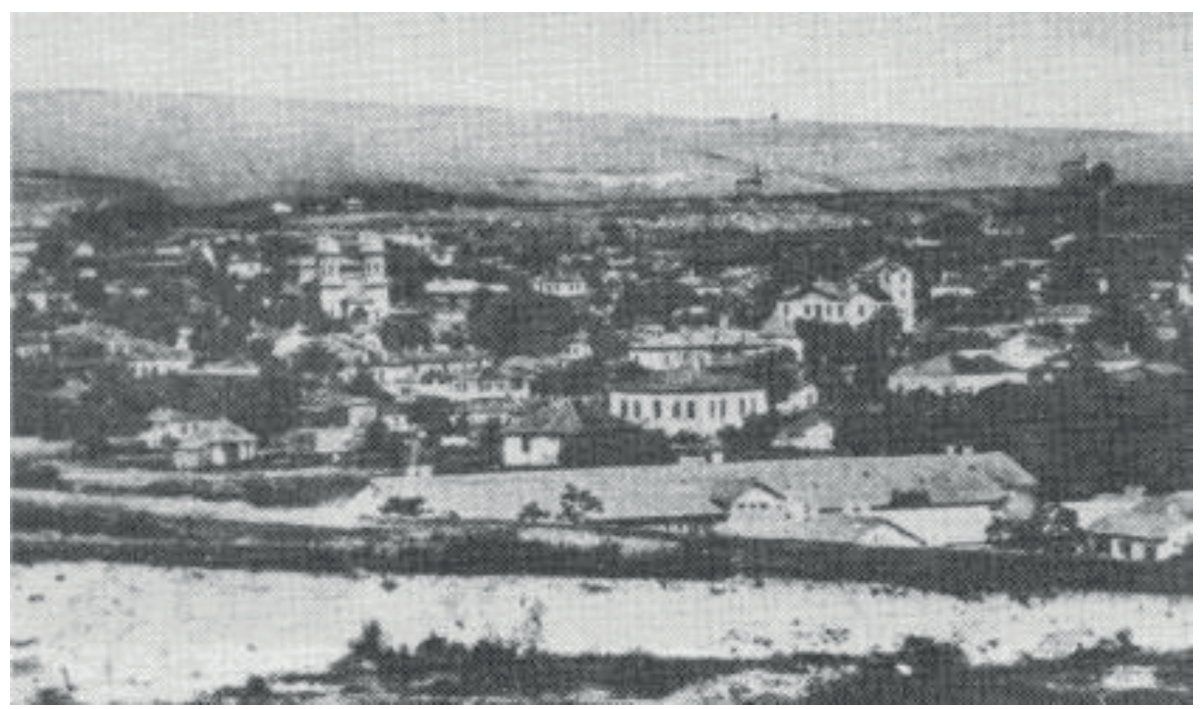

\section{Yusuf Ağa bin Salih ve Arkadașları Vakfı ${ }^{13}$}

20 arkadaşı ile beraber Hacı Salih oğlu Yusuf Ağa'nın, toplamda 2.775 kuruşu günümüzde Yunanistan sınırları içerisinde yer alan Gümülcine'de 1902 yılında kurduğu vakıf Burhaneddin Köyü Camisi’nin bakım ve tamir masraflarını temin etmek için faaliyet göstermiştir. Vakfiyede, vakfedilen paranın borç verilirken, borç kullanandan güçlü/değerli bir ipotek veya güvenilir bir kefil talep edilmesi, borç kullanandan herhangi bir operasyon gideri istenmemesi şartları sunulmuştur. İşletim oranı ise istirbah ile yüzde 12 olarak belirlenmiştir. Vakfın mütevellisi olarak Yusuf Ağa bin Salih tayin edilmiştir. Vakfiyede müçtehit imam görüşlerine, Bakara Suresi 181. ayete, tescil tarihine ve şahitlerin isimlerine de tanık olunmaktadır.

13 Vakıflar Genel Müdürlüğü Arşivi (VGMA), Defter No: 600, Sayfa: 182-183, Sıra: 223, 27 Ramazan 1320 / 28 Aralı 1902 
Tablo 1. Örnek Para Vakıfları Özeti

\begin{tabular}{|l|l|l|l|l|}
\hline VAKIF ADI & $\begin{array}{l}\text { Hacı Murtaza } \\
\text { Çelebi bin Hacı } \\
\text { Ahmed }\end{array}$ & $\begin{array}{l}\text { İbrahim Efendi } \\
\text { bin Hacı Suphi }\end{array}$ & $\begin{array}{l}\text { Ahmed Ağa ibn } \\
\text { İsmail Vakfı }\end{array}$ & $\begin{array}{l}\text { Yusuf Ağa } \\
\text { bin Salih ve } \\
\text { Arkadaşları }\end{array}$ \\
\hline ÜLKE & Bulgaristan & Edirne & Romanya & Yunanistan \\
\hline ZAMAN & 20 Şubat 1678 & 28 Aralık 1696 & 20 Kasım 1723 & 28 Aralık 1902 \\
\hline SINIFI & Reaya & Reaya & Reaya & Reaya \\
\hline SERMAYE & 1.000 kuruş & 5.000 kuruş & 300 kuruş & 2.775 kuruş \\
\hline İŞLETIM ORANI & $\% 15$ & $\% 15$ & $\% 15$ & \%12 \\
\hline BORÇLU & tüccar & tüccar & Tüccar & belirtilmemiş \\
\hline YÖNTEM & $\begin{array}{l}\text { istiğlal ve } \\
\text { istirbah }\end{array}$ & $\begin{array}{l}\text { istiğlal ve } \\
\text { istirbah }\end{array}$ & $\begin{array}{l}\text { mu'âmele-i } \\
\text { şer'iyye ve } \\
\text { murâbaha-i } \\
\text { mer'iyye }\end{array}$ & istirbah \\
\hline AMAÇ & $\begin{array}{l}\text { Dini, eğitim, } \\
\text { altyapı, hayır } \\
\text { hizmetleri }\end{array}$ & Dini & Dini & Dini \\
\hline
\end{tabular}

\section{VE 19. YÜZYILLAR ARASINDA AVRUPA'DA FINANS KURULUȘLARI}

İktisadi kalkınma üzerine çalışmalar yapanlar Batı ve İslam toplumları arasındaki gelişmişlik farkını incelerken merkantilist döneme ve onu izleyen kapitalist dönemdeki finansal gelişmeleri incelemiştir. Batı iktisadi zihniyetini büyük ölçüde Hristiyanlık etkilemiştir. Burjuvazinin ortaya çıkışı, Reform ve Rönesans hareketleri, Hristiyanlığa rasyonalite kazandırma çalışmaları olarak tanımlanabilir. Bu hareketler ve gelişmeler Hristiyanlığın kapitalist iktisadi zihniyeti dizginlediği özelikleri budamıştır. Dolayısı ile denilebilir ki kapitalizmin tarihi Hristiyanlıktan sapma tarihidir. Kapitalizm, merkantilizm yani ticari kapitalizm ile 15. yüzyılda Avrupa'da başlamış ve 18. yüzyılın sonlarına kadar sürmüştür. İktisadi zihniyetin yanında dini inanç da bu dönemde Allâh inancından insanperestliğe evirilmiştir. Sermaye birikiminin sömürgecilik faaliyetleri ile başladığı Batı daha sonra bu sermaye birikimi sayesinde Sanayi Devrimi gerçekleşmiştir (Tabakoğlu, 2010). Sermaye birikiminin varlı̆̆ bu birikimden kâr elde etme isteği doğurmuş ve bu sermayenin çeşitli şekillerde borç olarak, ortaklık modelleriyle yahut faizli olarak değerlendirilmesini sağlayan kurum ve kuruluşlar oluşmuştur.

Bu kurumlar ve zihniyet, Hristiyanlığın kapitalizme engel olan özelliklerinin ayıklanması ve dinden giderek uzaklaşması sürecidir. Bu süreci Protestanlık-Kapitalizm ekseninde Weber (Ö: 1920) ve Yahudilik-Kapitalizm 
ekseninde Sombart (Ö: 1941) incelemiştir. Sombart, Batı'nın bu iktisadi zenginleşme sürecini sömürgeciliğe bağlamıştır (Tabakoğlu, 2010).

\section{Anonim Șirket ve Borsa}

Anonim şirket, şahısların bizzat birey olarak olan sorumluluklarını şirketin üzerine transferini sağladığı için İslâm toplumlarında oluşmamıştır. Özellikle 15. yüzylldan sonra merkezi otoritenin Avrupa'da güçlenmesi siyasal açıdan istikrarı sağlamıştır. 12. ve 13. yüzyıllardan itibaren ticaretin gelişmesiyle ve özellikle 15. yüzyıldan sonra da istikrarlı yatırım ortamı ile 16. yüzyıldan itibaren Anvers, Londra ve Lyon gibi ticari merkantilizmin merkezlerinde menkul kıymetlerin alınıp satıldığı borsalar oluşmuştur. Bu süreç sonucunda ise anonim şirketler oluşmuş ve sermaye birikimi artan kârlar ile büyümüştür (Hamitoğulları, 1982, s. 43).

Yeterli büyüklüğe ulaşmış tüccarlar 16. yüzyıldan itibaren küçük zanaatkârları da ele geçirmeye başlamış ve bu zanaatkârlar kendi işlerinde ücretli işçiler olmuştur. Ayrıca ülke içinde üretimin artması dış pazarlar arayışını artırmıştır. Bu sayede devletlerin desteği ile büyük tüccarlar dış pazarlara açılma imkanu bulmuştur. Daha büyük işlemlerin varlığı daha büyük şirketlerin kurulması zorunluluğu doğrumuştur ve böylece yeni sözleşmeler yapılmış ve anonim şirketler kurulmuştur. 1553 yılında İngiltere Kralı VI. Edward'in destekleri ile kurulan ve daha sonra ismi Moskova Şirketi olarak değişen Yeni Topraklara Maceracı Tüccarlar Şirketi (Company of Merchant Adventurers to New Lands) 240 yatırımcının hisselerini aldığı nir anonim şirketti. Şirketin amacı Çin ve Baharat adalarına giden yeni yollar aramaktı. 1588 yılında özellikle Hindistan ile ticaret yapan Doğu Hindistan Şirketi de kurulan büyük anonim şirketlerden birisiydi. Hisseleri zenginlere ait olan bu şirketin Hindistan'ı büyük ölçüde kontrol eden bir de ordusu vardı. İngiltere'de XVII. yüzyılın sonlarına kadar bu özelliklere sahip bir çok şirket kurulmuştur (Hamitoğulları, 1982, ss. 50-51). Bu çok ortaklı büyük şirketlerde karar alma yetkisi hissedarlar tarafindan belirli bir yönetim organına devredilmiştir. Bu yönetim üretim ve yatırım kararları alma konusunda yetkilidir. Anonim şirketlerde hisse sahipleri hisseleri oranınd sorumlu iken şirketin tüzel kişiliği ile üstlendiği sorumluluklardan muaf tutulmuşlardır.

\section{Banka}

Banka, sermaye birikiminin sonucu ortaya çıkan ve insanların fazla servetlerinden kâr etme arayışının sonucu olan bir kurumdur. Her ne kadar 
Babil'in Hammurabi kanunlarında yahut Roma hukukunda faiz uygulamaları ile ilgili delillere rastlamış olsak da günümüzdeki modern bankacıllı̆̆ın temelleri Orta Çağ'dan itibaren Avrupa'da atılmıştır. 1246 yılına ait Papa IV. Innocent'in göndermiş olduğu 25.000 gümüş marklık bir ödeme belgesi bulunmaktadır. Henri Raspon ismine ait bu belgeye ait ödeme Frankfurt'taki bir Venedik bankası tarafından yapılmıştır. Bu belgenin daha erken bir örneğine ise 1202 yılında rastlanmıştır. Haçlılar, kendilerini Suriye’ye götürecek gemiler karşıllğında Venedikliler tarafindan talep edilen 85.000 gümüş mark için Henri Dandolo adında bir ödeme belgesi düzenlemiştir. Bu dönemde para ticareti Avrupa'da Yahudiler tarafindan yönetilmekteydi ve para ticareti ile kazandıkları servet dönemin idarecileri tarafından da fark edilmişti. $\mathrm{Bu}$ sebeple Hristiyanları köleleştirmekle suçlanan Yahudilere sürgün dahil çeşitli yaptırımlar uygulanmıştır. Kısa süre sonra Yahudilerin sermaye piyasasından çekilmelerinin etkisi görülmüş ve Yahudiler tekrar geri çağrılmıştır. Bu durum birkaç kez tekrar etmiştir. Orta Çağ' 1 sonlarında banka gibi birçok şube açarak döviz değişim işlemleri gerçekleştiren ve Kral VII. Charles'a dahi büyük miktarlarda borç verebilen kişi bir tüccar olan Jacques Coeur idi. (A History of Banking in all the Leading Nations, 1896, ss. 2-4). Bu şekilde ticaret ve sömürgecilik faaliyetleri ile servetlerini biriktiren büyük tüccarlar nakit talebi olanlara faizli borç vererek âtıl halde duran sermaye birikimlerini de değerlendirmiştir. Kâr elde etmek amacıyla kurulan bu profesyonel işletmeler insanların borçlanma anlamında işlem maliyetlerini minimize ettiği için çok kısa sürede yayılmışlar ve şubeleşerek ülke genelinde faaliyet göstermeye başlamışlardır.

Banka terimi, İtalyancada banco kelimesinden gelmektedir. Bu kelimenin masa anlamı vardır. O dönemlerde para tüccarları yani faizli borç verenler paralarını bu masalarda tutmaktaydı. Onlara da yine aynı terimden türetilen banker ismi verilmiştir. Bankerler başarısızlığa uğradıklarında ise masaları kırılıyordu. İngilizce iflas anlamına gelen bankrupt da yine aynı kökenden gelmektedir (banco rotto). Fakat Orta Çağ'da banka terimi kullanışmamıştır. Cambiatores, Speciarii, Compsores, Argentarii, Nummudarii, Trapezita terimleri banka işlemini yapan kurumlara denilmiş tir. Ayrıca yine banker yerine Danista, Collybista ve Mutnatores gibi terimler kullanılmıştır. Venedik arşivlerinde 15. yüzyılda bankalara kullanılan birçok değişim makbuzuna (bill of exchange) rastlanmıştır. Genellikle ticari faaliyetler için kullanıldığ anlaşılan bu makbuzlar bir nevi banknot vazifesi de görmektedir. Dolayısı ile yaptığı faaliyetler açısından bir banker yeni borçlar oluşturarak para veya 
borç satın alan kişidir. Bankerin öncelikli işi ise birilerine borç vermek ve birilerinden de para toplamaktır (Macleod, 1866, ss. 108-111). Bu işlemlerde para toplarken banker bir gelir vadeder. Bu gelir faizdir. Borç verirken de borç verdiklerinden faiz talep eder. Verdiği faiz ve aldığı faiz arasındaki fark ise bankanın kârını belirlemektedir.

\section{PARA VAKIFLARI VE MODERN FINANS KURUMLARININ KARȘILAȘTIRILMASI}

Para vakıfları günümüz faizsiz finans kurumlarının öncüleri olup, dönemlerinde uyguladıkları usul ve yöntemler günümüzdeki faizsiz finans kurumlarına yol göstermektedir. Bunun yanında para vakıfları 1847'de Galata bankerleri tarafindan İstanbul'da kurulan Bank-1 Der Saadet'e kadar Osman$l_{1}$ finansal hayatında girişimcilerin kaynak bulabildiği en önemli finans kurumuydu. 1423'te kayıtlara geçen ilk Osmanlı para vakfını düşündüğümüzde para vakıflarının 400'ün üstünde sene bireysel finans konusunda kurumsal olarak tek oldukları söylenebilir. Çalışmanın bu kısmında aynı dönemde Avrupa'da sermaye birikimi ile ortaya çıkan ve Batı iktisadi zihniyetinin ürünü olan kurumlar ile Osmanlı para vakıfları arasında finansal, yapısal ve zihinsel bir karşılaştırma yapılacaktır.

\section{Finansal ve Yapısal Açıdan Karșılaștırma}

Para vakıfları, Batı'nın geliştirdiği finansal kurumlardan farklı bir yapısal özelliğge sahipti. Özellikle kurucunun kâr gayesi gütmemesi veya vakıf gelirinden pay almaması diğer bir ifadeyle gelirin tamamının toplumun faydasına harcanması finansal yapıyı da bu sınırlar içerisine yerleştirmiştir.

Bir diğer husus ise sermaye birikimi ile alakalıdır. Batı'daki bankalar sermaye oluşumuna izin verip sermayenin belirli gruplar ve kişilerde birikmesini sağlarken Osmanlılarda bunun önüne geçen uygulamalar yapılmıştır. Çizakça (2013) bu durumu şu şekilde ifade etmekteydi. Adam Smith'in sermaye birikimi için koymuş olduğu faiz oranlarının olan net kar oranının yarısı kadar olması gerektiği iddiası her ne kadar Batı için gerçekleştiyse de Osmanlılarda bu durum çok farklı olmuştur. Bu iddiaya göre Osmanlılarda sermaye birikimi için piyasada borçlanma oranları $\% 2,5-\% 10$ arasında ise ticaret, üretim gibi alanlarda kâr oranının \%5-\%20 arasında olması gerekiyordu. Oysa Osmanlı sermaye piyasalarında borçlanma oranları \%15-\%25 arasında gelişmiştir. Dolayısı ile bu durumda sermaye birikimi gerçekleşmemiştir (Çizakça, 2013). Fakat para vakıflarında uygulanan borçlanma oranları 
genel olarak \%10-\%15 bandında kalmıştır. Yani para vakıfları yapısı ve borç verirken uyguladıkları borçlanma oranları ile Çizakça'nın bahsetmiş olduğu sermaye birikimi için gerekli olan koşul olan;

$\frac{\text { Sermaye Piyasadındaki Borçlanma Oranı }}{\text { Pazarda Kâr Oranı (üretim,ticaret vb.) }}=\frac{1}{2}$

denklemini sağlayarak kısıtlı olsa da sermaye birikimi konusunda da girişimcilere bir firsat sunmaktadır.

Avrupa ülkelerinin çoğunda 16. ve 19. yüzylllar arasında faizler \%5-\%10 arasında oynaklık göstermektedir. Fransa'da 17. yüzyılda yaşanan yüksek faiz oranları hesaba katmadığımızda genel itibari ile bu oynaklık aşağı eğimli hareket etmiş fakat sabit bir orana erişilememiştir. Osmanlılarda ise borçlanma maliyetleri uzun dönemde sabit kalmıştır. Bu durumda kuşkusuz ulemanın bu konuda görüşünün olmasının ve yasal borçlanma oranları üzerine çıkanlara ceza verilmesinin büyük rolü vardır (Bulut \& Korkut, 2016, s. 65).

Avrupa'da faaliyetlerini gösteren bankalar ticari kuruluşlar oldukları için öncelikli amaçları kâr elde etmektir. Dolayısı ile profesyonel bir yönetim sistemine sahip olan bankalar şubeleşmekte ve ülkenin çeşitli yerlerinde faaliyet göstermektedirler. Oysa para vakıflarında ücretli mütevelliler olduğu kadar bu işi gönüllü olarak yerine getiren mütevellilerde mevcuttur. Ayrıca para vakıfları, bankalar gibi şubeleşerek değil tek merkezden çalıştıkları için nispeten daha bölgesel kurumlardır. Bunun yanında bankalar ticari şirket oldukları için vakıflar ise hizmetlerinin devamı için süreli değil ebedi faaliyet gösterme amacı ile kurulmuşlardır. Bankalar sahiplerinin menfaatleri için fayda göstermiş ve büyüme, kâr etme gibi ticari kaygılar güdülen kurumlar olmuştur. Para vakıfları ise ihtiyaç odaklı kurulmuş ve kurulduğu bölgede toplumun ihtiyaçlarına cevap verecek hizmetleri finanse etmiştir.

Para vakıflarının işleyişi üretim ve ticarete yani reel sektöre dayanmaktadır. İşlemlerde bir hizmet, gayrimenkul yahut mal kullanılmakta ve para üzerinden para kazanılmasının önüne geçecek uygulamalar yapılmaktadır. $\mathrm{Bu}$ durum bankaların temel işleyiş prensibine oldukça uzaktır. Zira bankalar faiz vererek fon toplamak ve faiz alarak borç dağıtmak temellerine inşa edilmiştir. Dolayısı ile para üzerinden para kazanmaya odaklı bir sistem olduğu için para vakıfları gibi ticaret ve üretim odaklı değil tüketim odaklı bir yapı oluşmuştur. Bunun yanında bankaları kuranlar büyük tüccarlar olup 
halihazırda çok büyük sermaye ve servet sahipleridir. Oysa para vakıflarında böyle bir durum söz konusu değildir. Gerek yönetici sinıftan gerekse reaya sınıfından gücü yetebilen kimseler para vakfı kurabilmiştir. Ayrıca çok küçük birikimi olanlar da bir araya gelerek belirli bir meblağ oluşturmuş ve bu meblağı vakfederek belki tek başlarına iken kurmaları mümkün olmayan vakıfları ortaklaşa kurabilmiştir.

\section{Zihniyet Açısından Karșılaștırma}

İslâm dini Batı'nın zenginleşmesine sağlayan sömürgecilik fikrine, sömürüye, adaletsizliğe, bireyselleşmeye, riba/faize, kumar ve spekülatif işlemlere yani kapitalizmin ekonomik olarak dayattığı sistemin bileşenlerine geçiş imkânı vermemektedir. Batı'nın gelişmesinde Sanayi Devrimi ve kapitalizmin yayılması konusunda Merkantilist dönemdeki sömürgecilik faaliyetlerinin ve köle sömürüsünün sermaye birikimi sağlamaları açısından büyük etkisi vardır (Tabakoğlu, 2010). Oysa Osmanlılar ve İslâm medeniyeti, dünya kapitalist sistemin tartışmasız üstünlüğünü kabul ederken 19. yüzyılın ortalarına kadar yani ilk bankanın kuruluşuna kadar bu sistem karşısında kendi ekonomik zihni ve kurumları ile direnebilmiştir. Başkalarının kaybettiği ve sadece birinin kazandığı sıfır sonuçlu oyun (zero sum game) olarak tanımlanabilecek bu tür bir ekonomik kalkınmaya zihin olarak yabancı olan İslâm medeniyeti bu sebeple Batı'ya göre görece maddi anlamda başarısız olmuştur.

Günümüzde iktisat tarihi Batı merkezli okunduğu ve Batı haricinde tarih araştırmalarının da yetersiz kalması sebebiyle kapitalizm genel geçer ve evrensel bir sistem olarak kabul edilmiştir. Karşıt ideolojilerin de kapitalizm merkezli çözümler yahut kapitalizmin sorunlarına yönelik eleştirileri de bu sistemin evrensel olarak kabul gördüğünün göstergesidir. Ahlâk ilminin bir kolu olan iktisat biliminin Sanayi Devrimi sonrasında ayrı bir ilim olarak kabul edilmesi ve ahlâk ilminin kendisine koyduğu kısıtların kalkmasıyla tasarruf merkezlikten tüketim merkezliliğe doğru zihnen kaymıştır. İktisat kitaplarının Batı merkezli olarak kapitalizm yahut Batı'nın batıl mezhebi olan marksizm ideolojilerine göre yazılması ve gelir edinimi, bölüşümü ve dağıtımı kavramlarının, emek-sermaye yaklaşımlarının bu ideolojiler çerçevesinde öğrenilmesine ve öğretilmesine sebep olmuştur. Bu dünyada başarilı olan öbür dünyada da başarıl olur fikri ile özetlenebilecek ve Yahudiliğin etkileriyle şekillenen Protestan-laik-burjuva ahlakı püriten ahlaktır. Bu sistemde 
homo-economicus modeli oluşturulmuştur ve ekonomik sistem tam rekabet merkezli kurgulanmıştır (Tabakoğlu, 2010: 98-100; Bulut 2015).

Dünyada kapitalist sistem hızla yaygınlaşırken ve büyük kapitalist ülkeler dünyanın çeşitli bölgelerinde sömürgeler elde edip ana kıta dedikleri Avrupa'ya bu sömürgelerdeki kaynakları transfer ederken, Osmanlıların ahlâkî ve iktisâdî zihin yapısı buna izin vermemiştir. Ekonomi ve finans gibi dünyevî kabul edilebilecek ihtiyaçlar, bu iktisâdî zihin yapısı çerçevesinde hayır hizmetleri odaklı gelişmiş ve vakıf merkezli bir finansal sistem kurulmuştur ve bu sistemin omurgasını para vakıfları oluşturmaktadır. Birincil amacı vakfin hayır hizmetlerini yerine getirmek olan para vakıfları, modern devletlerin günümüzde vatandaşlara sağlamış olduğu birçok hizmeti dönemlerinde bir sivil inisiyatif olarak yerine getirmiştir. Vakıf gelir kaynağını oluşturan nakit para ise nakit ihtiyacı olan girişimcilerin (çiftçi, esnaf, tüccar, üretici vb.) bu ihtiyaçlarını gidermiş ve ekonomide önemli bir işlevi yerine getirmiştir. Para vakıflarının borç verirken uygulamış olduğu yöntemler de Batı'nın faizli sisteminden farklı olarak İslâm'ın emir ve yasakları sınırları içerisinde mala yahut üretime dayalı olarak gelişmiştir.

Modern dönemde finansal krizlere borca dayalı para sisteminin temelini oluşturan faiz ve rezerv sistemi Batı'da gelişme imkânı bulmuştur. Önlenemez kâr iştahı ve büyüme isteği ile Protestan ahlâkı, Osmanlıların iktisadi zihin yapısı ile uyuşmamaktaydı. Özellikle para vakıfları gibi kurucusunun herhangi bir kâr ve gelir beklentisi olmadan sadece Allah'ın rızasını kazanmak için vakfetmiş olduğu nakit para, ticaret ve üretime dayandığı için ekonominin gelişmesini sağlamış vakfın gayesi ile de toplumun ihtiyaçları giderilmiştir. Tasavvufi hareketler ve tarikatlar ile yoğrulan Osmanlı toplumu, tasavvuf sayesinde insanların güç ve kazanç elde etme iştahını kontrol altına almıştır. Bu sayede insanlar kazandıklarını paylaşmayı öğrenmiştir. Vakıflar sayesinde ise sermaye ve servet transferi güçlü olandan zayıf olana aktarılma imkânı bulmuştur. Batı'nın sermayeyi belirli çıkar gruplarında veya kişilerinde toplanmasina sebep olan finansal yapısı ve iktisadi zihniyeti, Osmanlılarda bu sermaye ve servetin bölüşümü ve dağıtımını sağlamıştır. İnsanların fitrat dışı çalışma şekilleriyle köle gibi çalıştırılması ve sömürülmesi makroekonomik olarak ülke açıdan iktisadi kalkınmayı sağlayacak ise de İslâm'a ve ahlâka aykırı bu üretim Osmanlılar tarafından kabul görmemiştir. Osmanlı finansal ve iktisadi zihniyeti, kul hakkı yememeyi merkeze almış ve ibadullâhın terfi-i ahvâli olarak özetlenebilecek bir sistem kurarak Osmanlı tebaasının refahını artırmayı hedeflemiştir. Para vakıfları bu açıdan bireysel- 
leşmeyi merkeze alan ve hümanizm adı altında insan merkezliliği değil insan merkezciliği şiar edinmiş kapitalist anlayışa karşı toplumun refahını artırmayı amaç edinmiş ve İslâm iktisadının sosyalleşme yani toplumun faydasını bireyin faydasının önüne çıkarma ilkesi çerçevesinde faaliyet göstermiştir (Tabakoğlu, 2010, s. 125).

\section{Tablo 2. Osmanlı Para Vakıfları ve Modern Finans Kurumları Arasında Bir Karșılaștırma}

\begin{tabular}{|c|c|c|}
\hline KURUM & Osmanlı Para Vakıfları & Modern Finans Kurumları \\
\hline İŞLEMLER & İslâmî/Etik & Faize dayalı \\
\hline ZAMAN & 15. - 20. yüzyıllar arası & 15. yüzyıl - günümüz \\
\hline KURUCULAR & $\begin{array}{l}\text { Yöneticiler, reaya denilen sıradan } \\
\text { insanlar }\end{array}$ & $\begin{array}{l}\text { Genellikle büyük ve zengin } \\
\text { tüccarlar }\end{array}$ \\
\hline SERMAYE & $\begin{array}{l}\text { Vakfedilen paranın miktarının } \\
\text { önemi yoktur }\end{array}$ & $\begin{array}{l}\text { Büyük yatırımlar ve büyük } \\
\text { sermaye }\end{array}$ \\
\hline İŞLETİM ORANI & $\% 15$ & $\begin{array}{l}\text { Dönemin şartlarına göre } \\
\text { değişebilir }\end{array}$ \\
\hline BORÇLU & $\begin{array}{l}\text { Girişimciler (esnaf, tüccar, üretici } \\
\text { gibi) }\end{array}$ & Herkes \\
\hline KREDİ ÇEŞİDİ & Ticaret ve üretime dayalı & Çeşitli \\
\hline KREDİ BÜYÜKLÜĞÜ & $\begin{array}{l}\text { Mikrokredi - küçük-orta ölçekli } \\
\text { girişimcilere }\end{array}$ & Çeşitli \\
\hline KREDİ VADESİ & Genellikle bir yıl & $\begin{array}{l}\text { Yapılan sözleşmeye göre } \\
\text { değişir }\end{array}$ \\
\hline AMAÇ & $\begin{array}{l}\text { Dini, eğitim, altyapı, hayır } \\
\text { hizmetleri finansmanı ve Allah'ın } \\
\text { nzzasını kazanmak }\end{array}$ & Kâr elde etme \\
\hline $\begin{array}{l}\text { TÜKETICİ KREDİSİ } \\
\text { VEREBİLİR Mİ? }\end{array}$ & $\begin{array}{l}\text { Veremez (yapılan işlemlerin mal } \\
\text { veya ticari metaya dayanması } \\
\text { gerekir.) }\end{array}$ & Verebilir \\
\hline SERMAYE BİRİKİMİ & $\begin{array}{l}\text { Kisitl olarak vakfin sermaye } \\
\text { biriktirmesine izin verir }\end{array}$ & $\begin{array}{l}\text { Sermaye birikiminin } \\
\text { belirli grup veya kişilerde } \\
\text { toplanmasını sağlar }\end{array}$ \\
\hline FAYDASI & $\begin{array}{l}\text { Vakfin finanse ettiği hizmetler ile } \\
\text { bölge halkına ve kullanan herkese }\end{array}$ & Sahibine ve ortaklara \\
\hline $\begin{array}{l}\text { COĞRAFİ } \\
\text { YAYGINLIĞI }\end{array}$ & Bölgesel kurumlar & $\begin{array}{l}\text { Yurtiçi ve yurtdışında faaliyet } \\
\text { gösterebilir }\end{array}$ \\
\hline YÖNETIM & $\begin{array}{l}\text { Kurucunun kendisi veya atadığı } \\
\text { mütevelli }\end{array}$ & $\begin{array}{l}\text { Kurucu yahut profesyonel } \\
\text { kurum yönetimi (Genel Müdür } \\
\text { gibi) }\end{array}$ \\
\hline KAYNAK TRANSFERI & $\begin{array}{l}\text { Para ve bazen vakfin şartları } \\
\text { doğrultusunda mal }\end{array}$ & Her zaman para transferi \\
\hline ÇALIŞANLAR & $\begin{array}{l}\text { Gönüllü veya ücret tayin edilmiş } \\
\text { ise ücretli çalışanlar }\end{array}$ & Her zaman ücretli çalışanlar \\
\hline
\end{tabular}




\begin{tabular}{|l|l|l|}
\hline DEVLET DESTEĞİ & Yoktur. Sivil inisiyatif & $\begin{array}{l}\text { Özellikle büyük tüccarların } \\
\text { kurduğu bankalarda devlet } \\
\text { desteklerine rastlanmaktadır. } \\
\text { Ayrıca devletler de bu } \\
\text { kurumlardan borç almıştır. }\end{array}$ \\
\hline ÖNCELİK & Sosyal kalkınma & İktisadi Büyüme \\
\hline
\end{tabular}

\section{SONUC}

Bugün dünyada hâkim olan iktisadi düşünce Batı'da XV. yüzyıllardan itibaren merkantilizmin devamı olarak gelişen kapitalizmin sonucudur. Dolayısı ile günümüzdeki ekonomik ve finansal sorunlara çözüm aranıyorsa öncelikle bu sistemin doğuşu ve kökleri incelenmelidir. Soruna sebep olan sistemin bu sorunlara çözüm üretmesini beklemek hatadır. Günümüzde küresel ekonomide büyük ağırlığı olan bankacılık ve rezerv sistemi uzun yıllar piyasada para yaratma mekanizması ile finans sektörü ile reel sektör arasında önemli bir fark oluşturmuştur. Bu fark yüzünden yaşanan sanal büyümeler bir süre sonra sönmüş ve krizler meydana gelmiştir. Ana akım iktisadi fikirlerin ilkelerine dayanan ekonomi ve insan tanımının problemlere çözüm olmadığ1 görülmüsşür. Bu sebeple sistem kendisine çözümler aramaktadır. Burada üzerinde durulması gereken nokta sisteme alternatif sunma gerekliliğidir. Aksi halde dünyada kabul görmüş bu sistem alternatifleri kendisinin bir tamamlayıcısı olarak görmekte ve alternatifler yeni bir sistem oluşturmaya değil mevcut sistemin açıklarını örten ve bir nevi sorun bazlı iyileştirmeler yapan ufak çaplı revizyonlar olarak kalmaktadır. Eğer bir finansal ve iktisadi sistem önerisi yapılacak ve uygulanacak ise, kökleri insanları köle gibi çalıştırmaya ve sömürgeciliğe dayanan modern finansal sisteme yama değil alternatif sunulmalıdır.

Merkantilist ve kapitalist dönemin zihin yapısına uygun şekilde faaliyet gösteren bankalar ve tüm finansal sisteme karşı Osmanlı iktisadi zihniyeti kendine has kurum ve kuruluşları ile direnmiş ve dünyada kapitalist sistem yenilmez ve tek güç olarak görülürken bu sistemin temsilcisi Avrupa devletlerinin yanı başında kendine özgü finansal ve iktisadi uygulamalarıyla ayakta kalmıştır. Para vakıfları kurumu da bu uygulamalardan birisidir. Osmanlıların toplumun finansal ve iktisadi ihtiyaçlarını vakıflar üzerinden temin ettiği para vakıfları uygulaması beş asrı aşkın süre imparatorluğun en önemli finansal kurumlarından birisi olmuştur. 
Vakıf olarak toplumun temel ihtiyaçlarına yönelik faaliyet gösteren ve hizmetler sunan para vakıfları, sermayeleri yani gelir kaynakları ile de çiftçi, esnaf, girişimci, tüccar ve üretici gibi iktisadi hayatın önemli faktörlerinin finansal ihtiyaçlarını İslâmî usul ve uygulamalar ile tedarik etmiştir. Bunun yanında özellikle Avrupa'da gelişen merkantilizm yani ticari kapitalizm anonim şirket ve banka gibi kurumları ile sermayenin belirli gruplarda ve kişilerde toplanmasına sebep olmuştur. Hali hazırda devlet destekli coğrafi keşifler ve sömürgeci ticaret ile zengin olan tüccarlar, servetlerinin durdukları yerde de kazanması için faizli borçlar veren aracı kurumlar olan bankaların kurulup yaygınlaşması paranın tekrar bu kurumlara ve zengin tüccarlara dönmesini sağlamıştır. Osmanlılarda ise doğal süreç ve kurulan iktisadi sistem servetin tekelleşmesine izin vermeyip toplumun tabanına yayılmasını sağlamaya çalışmıştır. Vakıflar ve özelde para vakıfları bu servet transfer kanallarından birisidir.

Günümüzde modern finansal sistemin sebep olduğu finansal krizlerden sonra alternatif arayısları İslâmî finans usullerini ön plana çıkarmaktadır. Modern iktisadi zihniyetin temellerinin merkantilist dönemdeki uygulamalara ve o dönemin homo-economicus tanımlı insanına dayanması krizleri körüklemektedir. Dolayısı ile dayandığı temeller ve kökleri itibari ile bu sistemin kendi problemlerine çözüm üretmesi olası değildir. Bulunan çözümler geçici ve mevcutta yaşanan sıkıntıları giderip devam etmeye yöneliktir. Oysa İslâm'ın öngördüğü iktisadi düşünce ve tarihteki uygulamalar bu sorunlara ciddi bir alternatif sunmaktadır. Bu alternatiflerden birisi hayır ve vakıf merkezli bir finansman uygulaması olan para vakıflarıdır. Modern sistemdeki faiz ve rezerv para sisteminin yaşattığ finansal sektör ve üretim sektörü arasındaki uçurumu İslâmî ve ahlaki para işletme usulleri ile giderebilecek ve finans sektörü ile üretim sektörü arasındaki bağlantıyı tesis edecek yapıya sahip para vakıfları bu açıdan modern İslâmî ve faizsiz finans kurumları gibi faaliyet gösterebilir. Ayrıca ticari bir kurum olmadıkları için sürekli büyüme güdüsü ve kâr etme iştahı da ahlaki problemlerin (moral hazard) önüne geçecektir. Günümüzde de eğer birleşip bir fon oluşturmayacaklar ise para vakıfları çok büyük sanayicileri ve tüccarları değil küçük ve orta ölçekli girişimcileri finanse eden ve onlara mikro kredi sağlayan finansal kurumlar olarak faaliyet gösterdiklerinde toplumun alt ve orta tabakasını üste taşıyabilecek ve onların refahını artırabilecek bir finansal sistem kurabilir. Sürdürülebilir kalkınmanın önemli basamaklarından birisi olan alt ve orta gelir grubunun refahını artırmak bu açıdan da önemlidir. 
Para vakıflarının diğer özellikleri ise çoğunlukla modern toplumun sosyal yönleri ile ilişkilidir. Küreselleşme ve bireyselleşmenin artmasıyla baş gösteren sorunlar aslında vakıf sisteminin sunduğu çözümler ile asgariye indirilebilir. Vakıflar ve para vakıfları bölgesel kurumlardır yani bulundukları bölgenin hayat kalitesini yükseltmeye çalışan ve o bölgedeki insanlara hizmet eden kurumlar olarak faaliyetlerini sürdürmektedirler. Para vakıflarından borç kullananlar da yine aynı bölgenin girişimcileri, tüccarları ve üreticileridir. Dolayısı ile para vakıfları bölgesel kalkınma için önemli bir fonksiyon görmektedir. Aynı zamanda sunmuş oldukları hizmetler itibari ile de vakıflar / para vakıfları ihtiyaç odaklıdır. Bireyselleşmenin arttığı ve karşılıklı yardımlaşmanın bireylerden zorunlu bir şekilde devletlere geçtiği modern topluma, vakıflar ve vakıf kurucuları karşılık beklemeden iyilik yapmanın erdemini gösterebilirler. Kurucuların toplumun ihtiyaçlarını görerek kurmuş olduğu vakıflar altyapı hizmetlerinden dini hizmetlere, eğitim hizmetlerinden hayır hizmetlerine kadar birçok alanda vatandaşlara hizmet sunmuştur. Vakıf kültürünün desteklenmesi, yaşatılması ve yayılması bu sebeple önemlidir.

Temelleri merkantilist döneme dayanan modern kapitalizm kurum ve uygulamaları ile modern dünyanın tek hâkim sistemi gibi görülmektedir. Oysa sistem ne olursa olsun daha çok kazanma ve sonrasında daha çok tüketme fikri üzerine inşa edildiği için kolay kazanma yöntemi (para üzerinden para kazanma) olan finans sektörü ile ticaret ve üretime dayanan reel sektör arasındaki fark gittikçe büyümüsstür. Faiz ve kapitalist ahlâk servetin belirli gruplar ve kişilerde toplanmasını sağlamakta dünya genelinde gelir adaletsizliği konusunda en zengin ve en fakir arasındaki uçurum giderek açılmaktadır. Bu sisteme çözüm sunabilecek medeniyet ise İslâm medeniyetidir. Alternatifler ise İslâm medeniyetlerinin bugüne dek kurmuş oldukları kurumlarda ve uygulamış oldukları usul ve metotlarda gizlidir.

\section{KAYNAKCุA}

Çam, M. (2014). Vakıf Müessesi ve Para Vakıfları. Lira - Bülten, 35-41.

Çağatay, N. (1969). Osmanlı İmparatorluğu'nda Riba-Faiz Konusu Para Vakıfları ve Bankacılık. Vakiflar Dergisi(9), 39-56.

Çizakça, M. (2013). Gerçekten de Suçlu Şeriat mıydı? 12, 2017 tarihinde Academia.edu: https:// www.academia.edu/4588011/Gercekten_de_Suclu_Seriat_miydi adresinden alındı

Özcan, T. (2000). İbn Kemal'in Para Vakıflarnna Dair Risâlesi. İslâm Araştırmalan Dergisi(4), 3141. 
A History of Banking in all the Leading Nations (Cilt III). (1896). New York: Journal of Commerce and Commercial Bulletin.

Berki, A. H. (1962). Vakıf Kuran İlk Osmanlı Padişahı. Vakıflar Dergisi(5), 127-129.

Bulut, M. (2015) “Ahlak ve İktisat” ADAM AKADEMİ Sosyal Bilimler Dergisi, Cilt 5, Sayı: 2, s. 109127.

Bulut, M., \& Korkut, C. (2016). Finansal İstikrar ve Para Vakıflarn Etkisi: Rumeli Para Vakıflarn Örnekleri. İslam Ekonomisi ve Finansı Dergisi, 55-76.

Döndüren, H. (1992). İslâm Bankacılığı ve Risk Sermayesi. İslâmi Araştırmalar Dergisi, 6(1), 17 31.

Gökbilgin, M. T. (1952). XV.-XVI. Asırlarda Edirne ve Paşa Livâsı: Vakıflar, Mülkler, Mukataalar. İstanbul: İstanbul Üniversitesi Edebiyat Fakültesi Yayınlan, No: 508, Üçler Basımevi.

Hamitoğullan, B. (1982). Çağdaş İktisadi Sistemler Oluşum ve Değişim Aşamalan ile Strüktürel ve Doktrinal Bir Yaklaşım (3 b.). Ankara: Ankara Üniversitesi Basımevi.

Kudat, A. (2015). Bir Finans Enstrümanı olarak Nukud Vakfi ve In`Ikad Formülasyonu. İslam Ekonomisi ve Finansı Dergisi, 1(2), 55-81.

Macleod, H. D. (1866). The Theory and Practice of Banking (2. b., Cilt 1). Londra: Longmans, Green, Reader \& Dyer.

S. A. (1910/1328). Ingiltere ve Âlem-i İslâm . İstanbul: Matbaa-i Âmire.

Siddıki, M. (1982). Recent Works on History of Economic Thought in Islam: A Survey. International Center for Research in Islamic Economics, Research Series in English No.12. Jeddah: King Abdulaziz University.

Sayı, A. (1987). Faiz ve Faizin Tarihi Gelişimi. A. Tabakoğlu, \& İ. Kurt içinde, Faizsiz Yeni Bir Banka Modeli (Faizsiz Kredileşme Sistemi) (s. 19-37). İstanbul: İslâmî İlimler Araştırma Vakfi Yayınlarn.

Şeyhülislam Yenişehirli Abdullah Efendi. (2011). Behcetü'l-Fetâvâ. (S. Kaya, B. Algın, Z. Trabzonlu, \& A. Erkan, Dü) İstanbul: Klasik Yayınevi.

Tabakoğlu, A. (2010). İslâm İktisadı ve Modern Kapitalizm. Sosyal Piyasa Ekonomisi ve İslâm'daki Algılanışı (s. 91-133). Ankara: Konrad-Adenauer-Stiftung e.V. 